\title{
Mechanical properties of hybrid Cr, Mn, and Si-containing PM steel when sintered in a local micro-atmosphere
}

\author{
A. Cias* \\ Faculty of Metals Engineering and Industrial Computer Science, Department of Physical Metallurgy and Powder \\ Metallurgy, AGH - University of Science and Technology, A. Mickiewicza 30, 30-059 Krakow, Poland
}

Received 24 March 2015, received in revised form 10 November 2015, accepted 11 November 2015

\begin{abstract}
Fe-1.4Cr-1.3Ni-0.7Mn-0.2Mo-0.2Si-(0.5-0.6)C steel was sintered in semi-closed containers at 1120 or $1250^{\circ} \mathrm{C}$ using nitrogen or air as the furnace gas and also conventionally sintered in $\mathrm{N}_{2}-5 \% \mathrm{H}_{2}$. Additives, principally ferromanganese, the source of $\mathrm{Mn}$ vapour, aluminium or naphthalene, the source of nascent carbon, and activators were included with the specimens. Sintered density, carbon, oxygen, and nitrogen contents were evaluated before mechanical testing. All mechanical properties obtained with semi-closed container sintering outperformed those resulting from comparable conventional sintering. The best combination of properties resulted from liquid phase sintering at $1250{ }^{\circ} \mathrm{C}$ in $\mathrm{N}_{2}$ with naphthalene $/ \mathrm{Na}_{2} \mathrm{CO}_{3}$ or $\mathrm{Al} / \mathrm{NH}_{4} \mathrm{I} / \mathrm{NaCl} / \mathrm{AlCl}_{3}$ additives. Properties included strain-to-failure of $\sim 4.5 \%$, the yield stress of 374 and tensile strength of $813 \mathrm{MPa}$. Results for air as the furnace gas were slightly inferior. This opens up the possibility of using conventional air furnaces for sintering ceramics to process PM steels to (near) full density to match the properties of their wrought counterparts.
\end{abstract}

K e y w or d s: sintered steels, sintering atmospheres, alloying elements

\section{Introduction}

Chromium and manganese influence hardenability and have been utilized as alloying elements in PM steels. It has also been shown that elements such as nickel, molybdenum, and silicon have a synergistic effect leading to enhanced hardenability when alloyed together. Although cheaper $\mathrm{Cr}$ and $\mathrm{Mn}$ steels are the most promising alloying elements for medium-to-high strength steels, and some pre-alloyed $\mathrm{Cr}$ materials have been developed, some with $\mathrm{Mn}[1,2]$, sintering of these alloys is not easy. A comparative study of Fe$-0.8 \mathrm{Mn}-0.5 \mathrm{C}$ manganese powder metallurgy steels obtained by various alloying methods [3] reported high brittleness of admixed materials to be connected with intergranular decohesion failure associated with manganese oxide formation on the grain boundaries. The main difficulty to overcome in these steels is the classical problem of the sintering atmosphere [4]. Whereas the oxides of nickel and molybdenum can be reduced during sintering at conventional sintering temperatures in atmospheres without strict dew point control, the oxides of chromium, manganese, and silicon cannot.

From the Richardson-Ellingham diagram oxidation of chromium $\left(1120^{\circ} \mathrm{C}\right)$ starts at $\sim 1 \times 10^{-14} \mathrm{~Pa}$ oxygen. In this case, the activity of chromium is 1 . In a pre-alloyed state the activity at the low amount of chromium can be set approximately equal to the weight percent of chromium. Fe-1.5Cr and $\mathrm{Fe}-3 \mathrm{Cr}$ steels (Astaloy CrL and CrM), respectively, can be sintered at normal belt furnace sintering conditions, i.e. at $1120^{\circ} \mathrm{C}$ in nitrogen and hydrogen mix atmospheres, as long as the partial pressure of oxygen is lower than $\sim 5 \times 10^{-13} \mathrm{~Pa}$ [5]. Consequently, chromium and manganese (which has an even higher affinity for oxygen) bearing steels, used for PM structural parts, frequently contain inclusions or films of $\mathrm{Cr}$ and $\mathrm{Mn}$ oxides. These alloys are thermodynamically unstable at the sintering temperature, and the process is often not repeatable. The deposition of chromium oxide on the primary surfaces of powder particles and grain boundaries is widely viewed as a major source of mechanical properties loss in $\mathrm{Cr}$ and Mn PM steels [6-

*Corresponding author: tel.: +48 12 6172587; fax: +48 12 6173190; e-mail address: cias@agh.edu.pl 
8]. Open interconnected porosity of PM steels forms paths through which the sintering atmosphere can permeate the alloy. Severe oxidation in such a case is due to a continuous supply of an oxidizing agent from the flowing protective atmosphere throughout the whole process of heating up, soaking, and cooling down.

Pure hydrogen and dissociated ammonia have previously been used as the atmospheres for sintering $\mathrm{Cr}$ steels. Pure hydrogen works well, but it is more expensive than many other gas compositions. Dissociated ammonia is cheaper, but subject to quality control problems when the furnace is not tight enough or the drying system used operates at less than maximum efficiency, since, it is believed, oxygen and water vapour can cause undesirable oxidation. More recently, cheaper nitrogen/hydrogen blends containing high levels of nitrogen have been used. Powder grades pre-alloyed with 1.5-3 wt.\% chromium can be successfully sintered at the conventional temperature $1120^{\circ} \mathrm{C}$ in well-monitored $\mathrm{N}_{2} / \mathrm{H}_{2}$ sintering atmosphere with oxygen partial pressure $<10^{-13} \mathrm{~Pa}$ and dew point $<-50{ }^{\circ} \mathrm{C}[6]$. Industrial sintering is usually done in continuous link belt conveyor furnaces with an enclosed muffle, where a mixture of hydrogen and nitrogen (optionally with $0.1-0.2 \%$ methane [7]) is used as the flowing sintering atmosphere. At $1120^{\circ} \mathrm{C}$, introducing more than approximately $0.3 \%$ methane causes carbon deposition on iron parts and in the furnace. Nitrogen/hydrogen sintering atmosphere systems can be run with very low dew points only if the sintering furnace is tight and gas ingress is minimized. The atmosphere buffering capacity (the ratio $\mathrm{H}_{2} / \mathrm{H}_{2} \mathrm{O}$ ) increases with increased proportion of hydrogen. Lean (down to 5-10\% hydrogen/nitrogen) blends have been recently successfully introduced $[9,10]$.

Another approach is to use semiclosed containers in e.g. a flowing nitrogen atmosphere and rely on the water-gas reaction to produce sufficient necessary hydrogen and carbon oxide. This proved successful both on a laboratory $[11,12]$ and semi-industrial scale [13]. Such technique overcomes totally safety, legislative and economic problems necessarily associated with the use of hydrogen and dissociated ammonia in the workplace. In its place are the additional costs associated with the use of semi-closed containers (sintering boxes), which currently find the little industrial application. Further, into the local micro-atmosphere of a semi-closed container, an element which oxidizes more readily than $\mathrm{Cr}$, e.g. $\mathrm{C}, \mathrm{Mn}, \mathrm{Al}$ can be introduced as the oxygen binder, since it has a higher oxidation potential than chromium $[14,15]$. From $700^{\circ} \mathrm{C}$, manganese vapour is actively present and ensures benign oxidation of manganese on pore surfaces in preference to that of chromium [16]. Additionally, a source of nascent carbon, more active than graphite, was introduced in the form of naphthalene. The steel reported on was $\mathrm{Fe}-3 \mathrm{Cr}-0.5 \mathrm{Mo}-0.6 \mathrm{C}$, and the semi-closed container had a labyrinth seal [15].

This paper deals with a copper-free $1.4 \mathrm{Cr}-1.3 \mathrm{Ni}-$ -0.7Mn-0.2Mo-0.2Si-(0.5-0.6) C hybrid steel sintered in a semi-closed stainless steel container with a glass seal. The steel composition simulates that of EN 102775 wrought steel (European name $34 \mathrm{CrNiMo6}$, similar to SAE/AISI 4140 and 4340 alloys; heat treatable steel for high strained automotive and motor construction components). Wrought $34 \mathrm{CrNiMo6}$ steel possesses high hardenability and a very good combination of strength, toughness, and wear resistance. Typical applications are heavy-duty parts such as gears. Sintered hybrid steel based on pre-alloyed powder that has $\mathrm{Cr}, \mathrm{Ni}$, and $\mathrm{Mn}$ as their principal alloy additions provides the desired hardenability and flexibility in material design. The steel has sufficient martensitic and bainitic hardenability to develop the desired microstructure during sinter hardening and sinter austempering - depending on the size of the PM part [17].

\section{Experimental materials and procedures}

Höganäs Astaloy CrL (Fe-1.5Cr-0.2Mo, 0.2\%O), commercial Elkem low carbon ferromanganese (77Mn-1.3C-balance Fe, particle size $<20 \mu \mathrm{m}, 0.6 \% \mathrm{O}$, supplier ERAMET Sauda, Norway), ferrosilicon (Fe$-45 \% \mathrm{Si}$, type 44.0 , particle size $<45 \mu \mathrm{m}, 0.8 \%$ O, supplier OFZ Istebné, Slovakia), electrolytic Ni powder, particle size $<45 \mu \mathrm{m}$, supplier Kola MMC - Norilsk Nickel Group, and ultra fine Höganäs CU-F graphite (99.5\% purity) were the starting powders.

Turbula mixing (metal powders + 0.55 wt.\% graphite) and die compaction at $660 \mathrm{MPa}$ of Fe-1.4Cr$-1.3 \mathrm{Ni}-0.7 \mathrm{Mn}-0.2 \mathrm{Mo}-0.2 \mathrm{Si}-0.55 \mathrm{C}$ ISO 2740 specimens were followed by sintering in a semi-closed stainless steel container with a labyrinth seal or a semi-closed container with a glass seal. In the latter system, a powder mixture of 40 wt. $\%$ glass $\left(73 \mathrm{wt} . \% \mathrm{SiO}_{2}-2 \mathrm{wt} . \%\right.$ $\mathrm{Al}_{2} \mathrm{O}_{3}-15$ wt. $\% \mathrm{Na}_{2} \mathrm{O}-10$ wt. $\left.\% \mathrm{CaO}\right), 50$ wt.\% quartz sand (96-98 wt.\% silica) and 10 wt.\% sodium metasilicate, $\mathrm{Na}_{2} \mathrm{SiO}_{3}$, also known as water glass or liquid glass (commercially available sodium silicate pentahydrate $\mathrm{Na}_{2} \mathrm{SiO}_{3} \cdot 5 \mathrm{H}_{2} \mathrm{O}$, also formulated as $\mathrm{Na}_{2} \mathrm{SiO}_{2}$ $\left.(\mathrm{OH})_{2} \cdot 4 \mathrm{H}_{2} \mathrm{O}\right)$, was packed in the gap between the two boxes (container with upper seal and covering shell [18]). Sintering took place in an airless local microatmosphere, thus preventing oxidation of the specimens. Sodium silicate glass melts at $810^{\circ} \mathrm{C}$, wets container walls well and exhibits satisfactory fluidity and negligible volatility up to $1150-1200^{\circ} \mathrm{C}$. This isolates the specimens, from the furnace atmosphere, allowing a slight overpressure at a temperature above $810^{\circ} \mathrm{C}$.

During the heating up of a container, air and gases evolving from the getter activators/energizers 
Table 1. Designation of the specimens and processing

\begin{tabular}{cl}
\hline Specimens ID & Processing \\
\hline $\mathrm{A}$ & $\mathrm{N}_{2}-5 \% \mathrm{H}_{2}$ furnace atmosphere, 1120 and $1250{ }^{\circ} \mathrm{C}$ \\
$\mathrm{B}$ & $\mathrm{N}_{2}$ furnace atmosphere, ferromanganese, 1120 and $1250^{\circ} \mathrm{C}$ \\
$\mathrm{C}$ & $\mathrm{N}_{2}$ furnace atmosphere, ferromanganese, $\mathrm{NH}_{4} \mathrm{I}, 1120$ and $1250^{\circ} \mathrm{C}$ \\
$\mathrm{D}$ & $\mathrm{N}_{2}$ furnace atmosphere, ferromanganese, naphthalene, 1120 and $1250^{\circ} \mathrm{C}$ \\
$\mathrm{E}$ & $\mathrm{N}_{2}$ furnace atmosphere, naphthalene, $\mathrm{Na}_{2} \mathrm{CO}_{3}, 1120$ and $1250^{\circ} \mathrm{C}$ \\
$\mathrm{F}$ & $\mathrm{N}_{2}$ furnace atmosphere, naphthalene, $\mathrm{Na}_{2} \mathrm{CO}_{3}$, ferromanganese, $\mathrm{NH}_{4} \mathrm{I}, 1120$ and $1250^{\circ} \mathrm{C}$ \\
$\mathrm{G}$ & $\mathrm{N}_{2}$ furnace atmosphere, ferromanganese, $\mathrm{Al}, \mathrm{NH}_{4} \mathrm{I}, \mathrm{NaCl}, 1120^{\circ} \mathrm{C}$, sinteraustempered \\
$\mathrm{H}$ & at 400 and $500^{\circ} \mathrm{C}$ for 60 min \\
$\mathrm{I}$ & Air furnace atmosphere, ferromanganese, naphthalene, $\mathrm{Na}_{2} \mathrm{CO}_{3}, \mathrm{NH}_{4} \mathrm{I}, 1120$ and $1250^{\circ} \mathrm{C}$ \\
\hline
\end{tabular}

and compacts escape unhindered through the porous seal material. Before a liquid seal is formed, the gases in the container expand and prevent the furnace atmosphere from entering the container. Once its melting point has been reached, the fused seal material spreads over the sand surface and wets the walls of the container housing, thereby sealing off the container from the furnace atmosphere. Any gases remaining in the container after the liquid seal has formed can bubble out through the fused material. After all expanding product gases from the sintering reactions have escaped, the container constitutes a hermetically sealed system [19].

During cooling, the viscosity of the glass-forming liquid increases by many orders of magnitude, which thus acts as a 'cut off valve' for the furnace atmosphere to which the specimens may be exposed. This is important because decreased temperature is not beneficial for oxide reduction. The fact that container is sealed during holding at a temperature and cooling down significantly alters the kinetics of the processes during the sintering of steel, e.g. chemical reactions, oxidation/reduction, carburizing/decarburizing, and transport of manganese through the gaseous phase. The thermodynamically calculated oxygen partial pressure in the semi-closed container should be below $\sim 10^{-13}$ $\mathrm{Pa}$ to have reducing conditions during sintering at $1120^{\circ} \mathrm{C}$ of steel powder pre-alloyed with $1.5 \% \mathrm{Cr}$.

The furnace atmospheres were: $\mathrm{N}_{2}-5 \% \mathrm{H}_{2}$ (Linde Backing gas 95/5, NEN-EN-ISO 14175, $\mathrm{H}_{2} \mathrm{O}<40$ ppm, $\mathrm{O}_{2}<40 \mathrm{ppm}$ ), technical nitrogen (Air Products, grade $\left.\mathrm{B}, 99.5 \% \mathrm{~N}_{2}, 0.5 \% \mathrm{O}_{2}, 25 \mathrm{ppm} \mathrm{H}_{2} \mathrm{O}\right)$ with a gas flow of $\sim 0.2 \mathrm{~cm}^{3} \mathrm{~min}^{-1}$ per $\mathrm{cm}^{2}$ of furnace tube cross-sectional area or air.

Designation of specimens, depending on their processing history, is presented in Table 1. For sinterhardening (all specimens except $\mathrm{G}$ ) the container was pushed into the hot zone of a stainless steel tube horizontal sintering furnace. The specimens were heated to the sintering temperature of 1120 or $1250^{\circ} \mathrm{C}$ at a rate of $75 \mathrm{~K} \mathrm{~min}^{-1}$, held for $60 \mathrm{~min}$, and cooled at approximately $64 \mathrm{~K} \mathrm{~min}^{-1}$ in the temperature range of 1100 $500^{\circ} \mathrm{C}$. The specimens were not tempered. For sinteraustempering (specimens $\mathrm{G}$ ), the steel was cooled rapidly from the sintering temperature $1120^{\circ} \mathrm{C}$ down to the bainitic region $\left(400\right.$ or $\left.500^{\circ} \mathrm{C}\right)$, then isothermally annealed for $60 \mathrm{~min}$, to complete the bainitic transformation, and subsequently cooled to the room temperature.

Compacts were simultaneously sintered with a ferromanganese powder ( $10 \mathrm{~g}$, Elkem Fe-77\% Mn$-1.3 \% \mathrm{C}$ - the donor of manganese) and aluminium foil, and/or solid naphthalene (the donor of carbon) placed additionally in the container with a small amount of ammonium iodide $\left(\mathrm{NH}_{4} \mathrm{I}\right)$ and/or sodium carbonate $\left(\mathrm{Na}_{2} \mathrm{CO}_{3}\right)$, sodium chloride $(\mathrm{NaCl})$ or aluminium chloride $\left(\mathrm{AlCl}_{3}\right)$ as activators/energizers. Specimens A, sintered in an open boat in an atmosphere of $95 \% \mathrm{~N}_{2} / 5 \% \mathrm{H}_{2}$, were used as the reference material.

Chemical analyses for oxygen, nitrogen, and carbon in the starting powder and the sintered alloys, measured on at least 3 specimens, were carried out according to ASTM E 1019-2 on Leco apparatus: TC-336 and CS-125, respectively.

For metallographic investigations on a Leica DMLM optical microscope, the samples were mounted in bakelite, polished and etched in Nital (3 wt.\% $\mathrm{HNO}_{3}-97$ wt.\% $\left.\mathrm{H}_{2} \mathrm{O}\right)$. Fractographic examinations were carried out in a Zeiss Merlin FE-SEM (field emission scanning electron microscope) equipped with EDS Quantax 830 and EBSD Quantax CrystAlign 200 systems.

The measured properties were: green and sintered densities (MPIF Standard 42), apparent crosssection hardness, HV30, tensile (fracture) strength, TS, strain-to-failure, A, and transverse rupture strength, TRS. Standard PN-EN ISO 2740 tensile specimens were tested on an MTS 810 servo-hydraulic machine at a strain rate of $5 \times 10^{-4} \mathrm{~s}^{-1}$. The same specimen types (ISO 2740) were tested in three-point bending to determine the (apparent) transverse rupture strength, TRS, for specimens of beam depth $t=6 \mathrm{~mm}$ and width $w=6 \mathrm{~mm}$, using span length $l$ of $28.6 \mathrm{~mm}$. These tests were conducted on a 


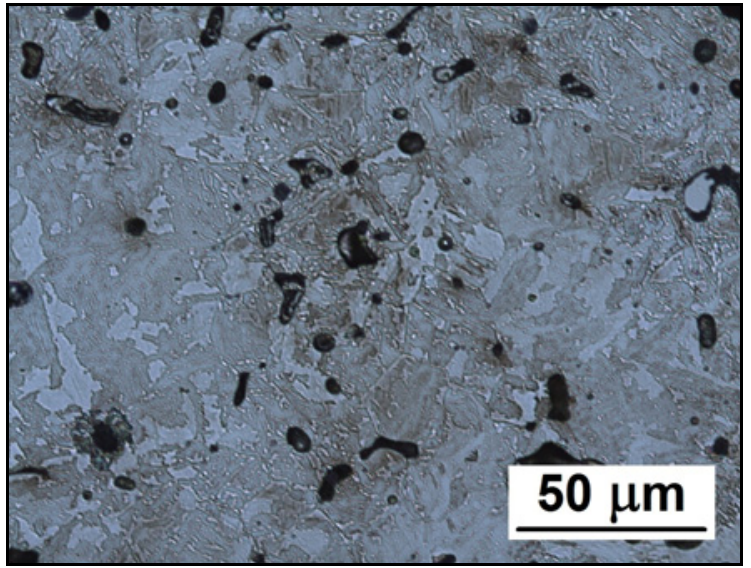

Fig. 1. Optical micrograph of specimen E after sintering at $1250{ }^{\circ} \mathrm{C}$ for $60 \mathrm{~min}$; note the small amount of austenite.

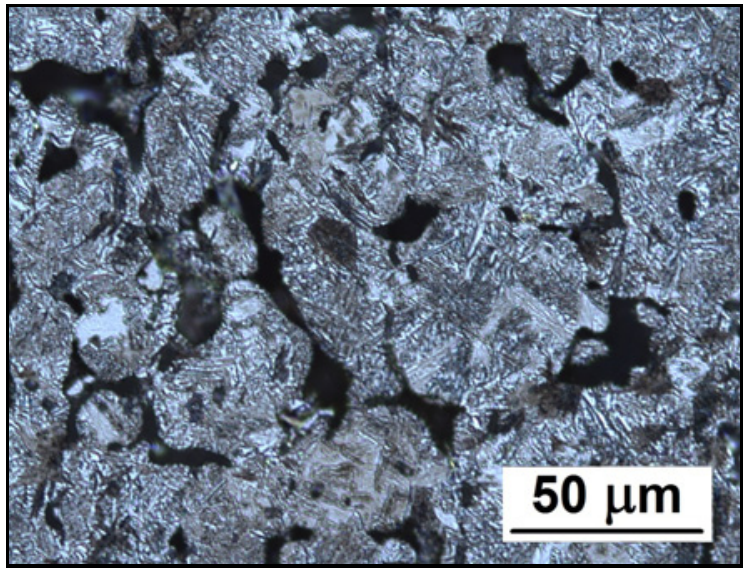

Fig. 2. Optical micrograph of specimen A after sintering at $1120^{\circ} \mathrm{C}$ for $60 \mathrm{~min}$; note the continuous oxide network.

W."Fritz Heckert" type 2010/90 machine equipped with a three-point bending jig at a crosshead speed of $2 \mathrm{~mm} \mathrm{~min}{ }^{-1}$. A plasticity correction was made to calculate the bending strength, BS (corrected TRS) [11].

\section{Results}

Green density of all the specimens was $6.79 \pm 0.03$ $\mathrm{g} \mathrm{cm}^{-3}$. The density data were fairly reproducible for each sintering condition. Sintered density varied from 6.78 to $6.99 \mathrm{~g} \mathrm{~cm}^{-3}$ and was practically unaffected by the sintering micro-atmosphere, but generally higher for the higher sintering temperature. Oxygen contents $0.111-0.226 \%$ were lower for sintering at $1250^{\circ} \mathrm{C}$, as were the carbon contents at $0.481-0.639 \%$. The level of the nitrogen content of $0.04 \%$ was insignificant.

The microstructure of specimens sintered at

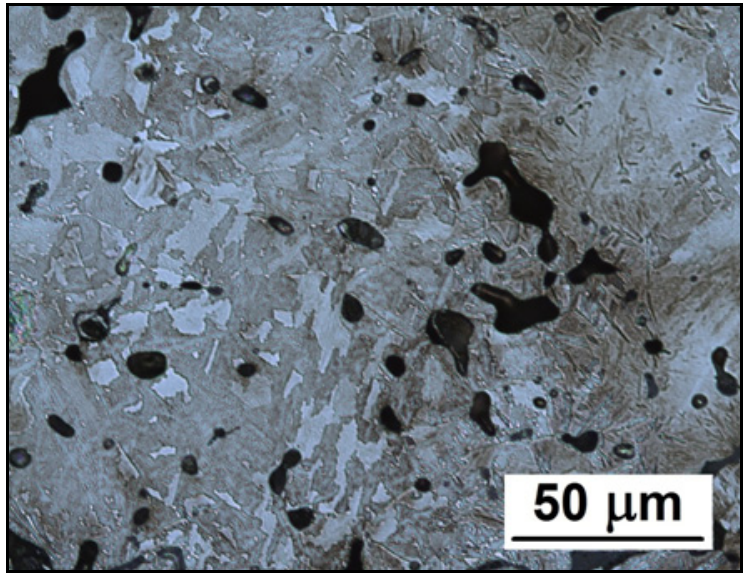

Fig. 3. Optical micrograph of specimen $\mathrm{B}$ after sintering at $1250^{\circ} \mathrm{C}$ for $60 \mathrm{~min}$; note an absence of a continuous oxide network.

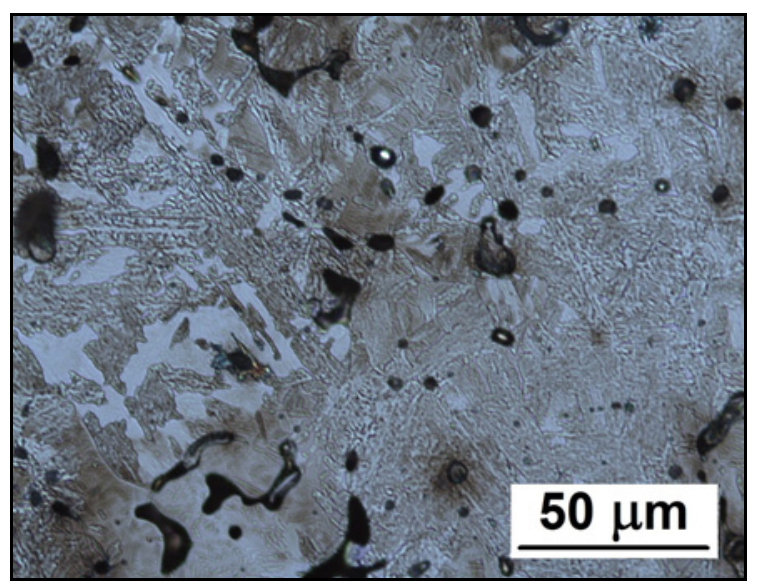

Fig. 4. Optical micrograph of specimen $\mathrm{C}$ after sintering at $1250^{\circ} \mathrm{C}$ for $60 \mathrm{~min}$; note an absence of a continuous oxide network.

$1120^{\circ} \mathrm{C}$ consisted of bainite, some martensite, and some divorced pearlite, with some areas of very fine troostic pearlite. For sintering at $1250^{\circ} \mathrm{C}$, a predominantly bainitic microstructure with some martensitic areas was seen. Elevated sintering temperature results in microstructures that contain significant amounts of martensite, and all specimens except $G$ were effectively sinter-hardened. The microstructure of material G sinter-austempered at $1120^{\circ} \mathrm{C} / 1 \mathrm{~h} 500^{\circ} \mathrm{C}$ or $1 \mathrm{~h}$ $400{ }^{\circ} \mathrm{C}$ consisted of bainite. Then even specimen $\mathrm{E}$ sintered at $1250^{\circ} \mathrm{C}$ has a small amount of austenite (rich in $\mathrm{Ni}$ and $\mathrm{Mn}$ ) in its microstructure (Fig. 1).

Detailed examination of the microstructure of the alloys revealed in specimens A (sintered in an open boat in technical nitrogen with $5 \%$ hydrogen added) a thick, nearly continuous network of grain boundary oxides, $\mathrm{SiO}_{2}$ and $\mathrm{MnO}$ (Fig. 2), while specimens $\mathrm{B}$ 


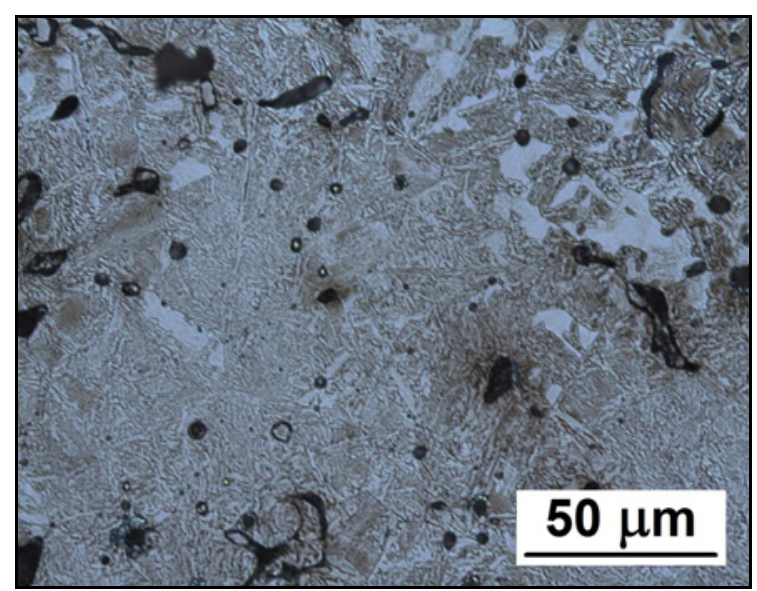

Fig. 5. Optical micrograph of specimen D after sintering at $1250{ }^{\circ} \mathrm{C}$ for $60 \mathrm{~min}$; note an absence of a continuous oxide network.
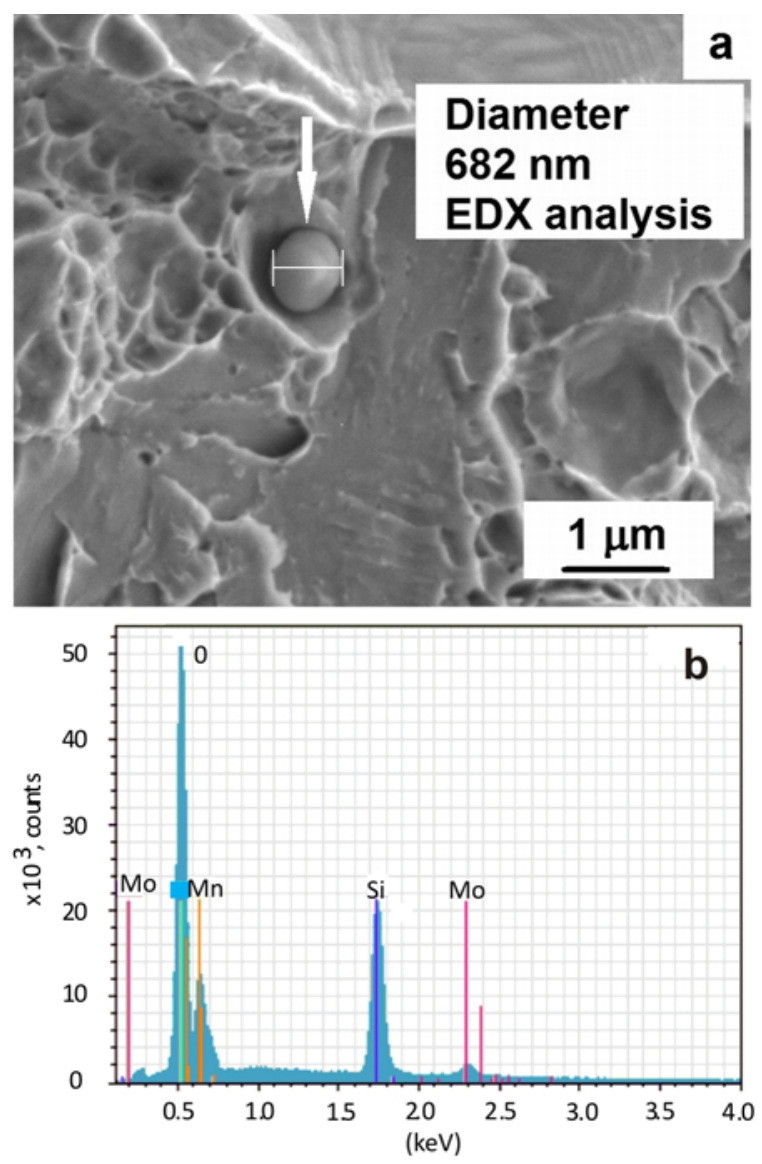

Fig. 6. SEM observation (a) and EDX spectrum (b) for specimen $\mathrm{D}$ after sintering at $1250^{\circ} \mathrm{C}$ for $60 \mathrm{~min}$; note an isolated oxide precipitate containing $\mathrm{Si}$ and $\mathrm{Mn}$.

and $\mathrm{C}$, sintered in a semi-closed container in technical nitrogen with ferromanganese added, did not exhibit these oxide networks (Figs. 3 and 4). In specimens
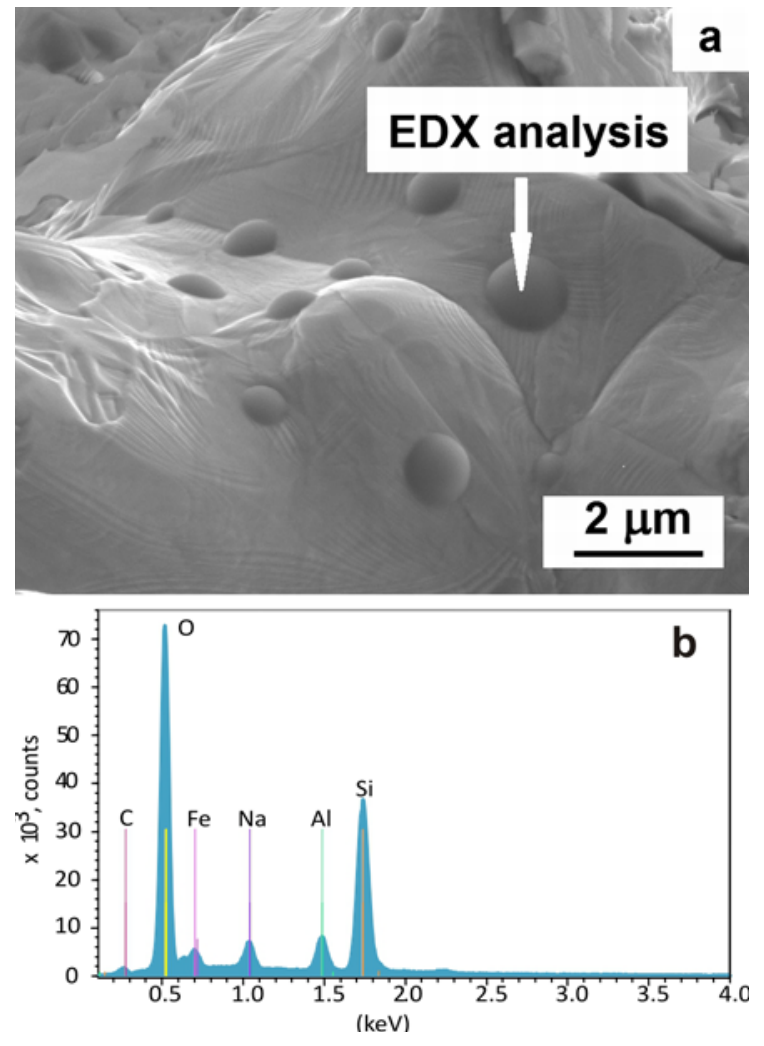

Fig. 7. SEM observation (a) and EDX spectrum (b) for specimen $\mathrm{G}$ after sintering at $1250^{\circ} \mathrm{C}$ for $60 \mathrm{~min}$; note an isolated oxide precipitate containing $\mathrm{Si}, \mathrm{Al}$ and $\mathrm{Na}$.

D, Fig. 5, manganese vapour and naphthalene present in the semi-closed container likewise reduced the level of grain boundary oxides. Similar results were found when naphthalene (specimens E) or ferromanganese and aluminium (specimens $\mathrm{G}$ and I) were added to the sintering atmosphere (Fig. 6). Inclusions in specimens $\mathrm{G}$ contained $\mathrm{Al}$ and $\mathrm{Na}$ (Fig. 7). The inclusions densities of specimens $\mathrm{H}$, as well as $\mathrm{A}$, were larger than for the other specimens.

Table 2 summarizes compositional data and density, hardness, yield and tensile strength, and strain to failure after different sintering treatments. All the specimens showed a small amount of ductility. Since some plastic strains were considerable, a plasticity correction was applied to TRS values to calculate the bending strength, BS. $0.2 \%$ offset yield stress was the least affected property at 343-436 MPa. Varying the sintering parameters had the most effect on tensile fracture strength, TS, which ranged from 424 to $813 \mathrm{MPa}$. BS varied significantly, from 981 to $1778 \mathrm{MPa}$, as did the strain to failure, from 1.04 to $4.77 \%$. The higher sintering temperature improved all properties except the yield stress significantly. Specimens A (from the open boat) had a lower hardness, TS, and BS than other specimens for both sintering temperatures. 
Table 2. Physical, chemical and mechanical properties of Fe-1.4Cr-1.3Ni-0.7Mn-0.2Mo-0.2Si-0.4C, together with some literature data for similar PM steel [25, 26] and MPIF Standard 35 FL-4605 data for similar PM low alloy steel pre-alloyed with nickel, molybdenum, and manganese for better hardenability. A plasticity correction was applied to TRS values to calculate the bending strength [24]

\begin{tabular}{|c|c|c|c|c|c|c|c|c|c|c|}
\hline 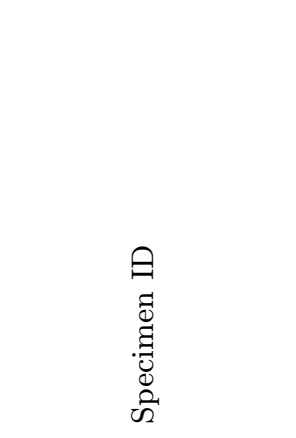 & 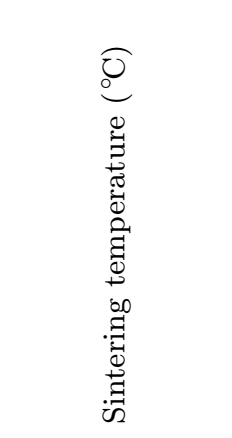 & 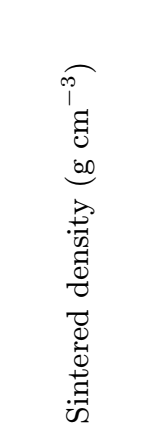 & 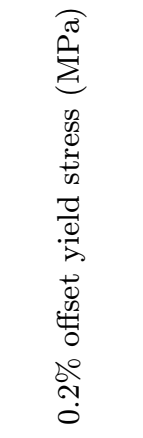 & 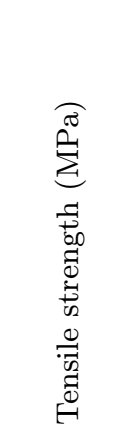 & 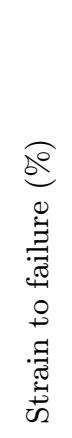 & 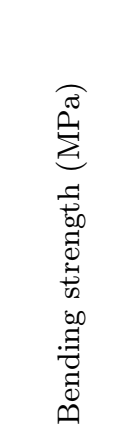 & 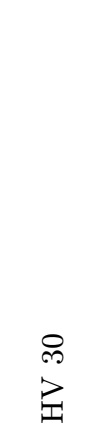 & 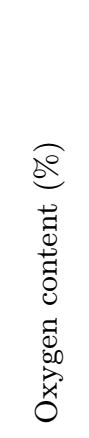 & 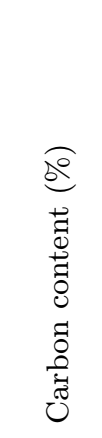 & 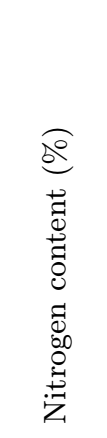 \\
\hline $\mathrm{A}$ & $\begin{array}{l}1120 \\
1250\end{array}$ & $\begin{array}{l}6.83 \\
6.85\end{array}$ & $\begin{array}{l}351 \\
378\end{array}$ & $\begin{array}{l}424 \\
508\end{array}$ & $\begin{array}{l}1.09 \\
1.79\end{array}$ & $\begin{array}{c}981 \\
1124\end{array}$ & $\begin{array}{l}198 \\
207\end{array}$ & $\begin{array}{l}0.226 \\
0.214\end{array}$ & $\begin{array}{l}0.505 \\
0.481\end{array}$ & $\begin{array}{l}0.0334 \\
0.0421\end{array}$ \\
\hline B & $\begin{array}{l}1120 \\
1250\end{array}$ & $\begin{array}{l}6.83 \\
6.87\end{array}$ & $\begin{array}{l}368 \\
361\end{array}$ & $\begin{array}{l}459 \\
619\end{array}$ & $\begin{array}{l}1.55 \\
2.60\end{array}$ & $\begin{array}{l}1052 \\
1369\end{array}$ & $\begin{array}{l}201 \\
242\end{array}$ & $\begin{array}{l}0.193 \\
0.151\end{array}$ & $\begin{array}{l}0.523 \\
0.511\end{array}$ & $\begin{array}{l}0.0415 \\
0.0475\end{array}$ \\
\hline $\mathrm{C}$ & $\begin{array}{l}1120 \\
1250\end{array}$ & $\begin{array}{l}6.80 \\
6.91\end{array}$ & $\begin{array}{l}343 \\
384\end{array}$ & $\begin{array}{l}524 \\
807\end{array}$ & $\begin{array}{l}1.64 \\
4.77\end{array}$ & $\begin{array}{l}1173 \\
1772\end{array}$ & $\begin{array}{l}221 \\
275\end{array}$ & $\begin{array}{l}0.159 \\
0.119\end{array}$ & $\begin{array}{l}0.518 \\
0.504\end{array}$ & $\begin{array}{l}0.0451 \\
0.0475\end{array}$ \\
\hline $\mathrm{D}$ & $\begin{array}{l}1120 \\
1250\end{array}$ & $\begin{array}{l}6.84 \\
6.92\end{array}$ & $\begin{array}{l}351 \\
374\end{array}$ & $\begin{array}{l}481 \\
767\end{array}$ & $\begin{array}{l}1.61 \\
4.51\end{array}$ & $\begin{array}{l}1053 \\
1675\end{array}$ & $\begin{array}{l}202 \\
264\end{array}$ & $\begin{array}{l}0.202 \\
0.111\end{array}$ & $\begin{array}{l}0.554 \\
0.538\end{array}$ & $\begin{array}{l}0.0451 \\
0.0436\end{array}$ \\
\hline $\mathrm{E}$ & $\begin{array}{l}1120 \\
1250\end{array}$ & $\begin{array}{l}6.85 \\
6.99\end{array}$ & $\begin{array}{l}375 \\
374\end{array}$ & $\begin{array}{l}516 \\
813\end{array}$ & $\begin{array}{l}1.80 \\
4.68\end{array}$ & $\begin{array}{l}1155 \\
1778\end{array}$ & $\begin{array}{l}212 \\
287\end{array}$ & $\begin{array}{l}0.190 \\
0.121\end{array}$ & $\begin{array}{l}0.639 \\
0.581\end{array}$ & $\begin{array}{l}0.0335 \\
0.0429\end{array}$ \\
\hline $\mathrm{F}$ & $\begin{array}{l}1120 \\
1250\end{array}$ & $\begin{array}{l}6.78 \\
6.78\end{array}$ & $\begin{array}{l}351 \\
344\end{array}$ & $\begin{array}{l}550 \\
609\end{array}$ & $\begin{array}{l}2.16 \\
2.66\end{array}$ & $\begin{array}{l}1235 \\
1373\end{array}$ & $\begin{array}{l}203 \\
239\end{array}$ & $\begin{array}{l}0.216 \\
0.186\end{array}$ & $\begin{array}{l}0.621 \\
0.616\end{array}$ & $\begin{array}{l}0.0418 \\
0.0411\end{array}$ \\
\hline $\mathrm{G}$ & $\begin{array}{l}1120 / 400 \\
1120 / 500\end{array}$ & $\begin{array}{l}6.82 \\
6.82\end{array}$ & $\begin{array}{l}436 \\
409\end{array}$ & $\begin{array}{l}668 \\
753\end{array}$ & $\begin{array}{l}2.7 \\
3.2\end{array}$ & $\begin{array}{l}1301 \\
1414\end{array}$ & $\begin{array}{l}270 \\
272\end{array}$ & $\begin{array}{l}0.208 \\
0.211\end{array}$ & $\begin{array}{l}0.528 \\
0.521\end{array}$ & $\begin{array}{l}0.0343 \\
0.0343\end{array}$ \\
\hline $\mathrm{H}$ & $\begin{array}{l}1120 \\
1250\end{array}$ & $\begin{array}{l}6.81 \\
6.84\end{array}$ & $\begin{array}{l}386 \\
399\end{array}$ & $\begin{array}{l}529 \\
562\end{array}$ & $\begin{array}{l}1.82 \\
2.11\end{array}$ & $\begin{array}{l}1181 \\
1249\end{array}$ & $\begin{array}{l}219 \\
223\end{array}$ & $\begin{array}{l}0.214 \\
0.201\end{array}$ & $\begin{array}{l}0.584 \\
0.536\end{array}$ & $\begin{array}{l}0.0327 \\
0.0315\end{array}$ \\
\hline I & $\begin{array}{l}1120 \\
1250\end{array}$ & $\begin{array}{l}6.77 \\
6.78\end{array}$ & $\begin{array}{l}376 \\
388\end{array}$ & $\begin{array}{l}678 \\
811\end{array}$ & $\begin{array}{l}2.6 \\
3.9\end{array}$ & $\begin{array}{l}1508 \\
1717\end{array}$ & $\begin{array}{l}234 \\
237\end{array}$ & $\begin{array}{l}0.107 \\
0.108\end{array}$ & $\begin{array}{l}0.524 \\
0.513\end{array}$ & $\begin{array}{l}0.0352 \\
0.0365\end{array}$ \\
\hline \multirow{2}{*}{$\begin{array}{l}\text { FL-4605 } \\
0.4-0.7 \% \text { C } 0.05- \\
-0.30 \% \mathrm{Mn} \\
0.45-0.60 \% \mathrm{Mo} 1.7- \\
-2.0 \% \mathrm{Ni}\end{array}$} & $\begin{array}{l}\text { Not specified; } \\
\text { as-sintered }\end{array}$ & $6.75-7.15$ & $290-60$ & $360-460$ & 1 & \multirow{3}{*}{$\begin{array}{c}\text { Not } \\
\text { specified }\end{array}$} & $\begin{array}{l}60-73 \\
\text { HRB }\end{array}$ & \multirow{3}{*}{\multicolumn{3}{|c|}{ Not specified }} \\
\hline & Heat treated & $6.75-6.95$ & $760-900$ & $760-900$ & $<1$ & & $\begin{array}{l}29-34 \\
\text { HRC }\end{array}$ & & & \\
\hline $\begin{array}{c}\text { Fe-2Ni-1.8Cr- } 0.55 \mathrm{C} \\
{[25,26]}\end{array}$ & $\begin{array}{c}1120^{\circ} \mathrm{C} \\
90 \% \mathrm{~N}_{2} / 10 \% \mathrm{H}_{2}\end{array}$ & 7.04 & $\begin{array}{c}\text { Not } \\
\text { specified }\end{array}$ & 900 & 1.2 & & 350 & & & \\
\hline
\end{tabular}

Sintering in a semi-closed container resulted in a moderate increase in TS and BS values for the specimens B, F, H and a significant increase in the values for the C, D, E, I specimens sintered at $1250^{\circ} \mathrm{C}$, as well as $\mathrm{G}$ specimens sinter-austempered at $1120 / 500^{\circ} \mathrm{C}$, when compared with A specimens sintered in the $\mathrm{N}_{2}-5 \% \mathrm{H}_{2}$ atmosphere. Specimens C, D, E, I also had higher tensile strain to failure, but this increase was only pronounced for the higher sintering temperature.
As would be expected, TS, BS, and apparent cross section hardness increased with increasing carbon content, but TS and BS are clearly less directly linked to carbon content than hardness. The apparent cross section hardness takes into account the hardness of the metal matrix but does not account for any stress concentrations that a higher level of microvoiding may cause. TS and BS decreased with increasing oxygen content. Specimens I sintered at $1120^{\circ} \mathrm{C}$ had TS of 


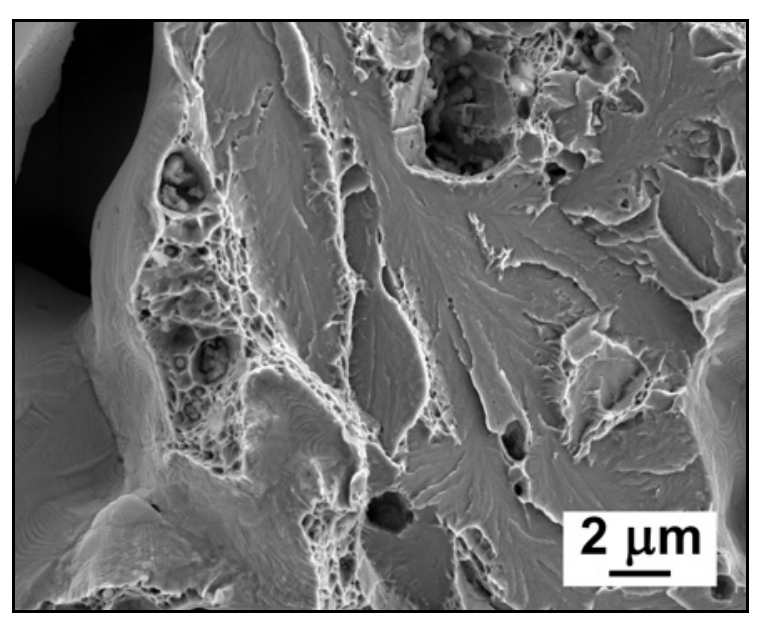

Fig. 8. Fractograph of specimen A after sintering at $1120^{\circ} \mathrm{C}$ for $60 \mathrm{~min}$.

$678 \mathrm{MPa}$ and specimens E sintered at $1250^{\circ} \mathrm{C}$ had TS of $813 \mathrm{MPa}$ - the highest among all the investigated groups.

The segregation of $\mathrm{Mn}$ and $\mathrm{Si}$ to grain boundaries, in the form of $\mathrm{MnO}$ and $\mathrm{SiO}_{2}$, is believed to degrade the bond strength [20]. This is consistent with the observed intergranular cracking due to weakened grain boundaries (Fig. 8). The characteristics of the fracture surfaces showed a considerable change as the micro-atmosphere and the sintering temperature were varied. When naphthalene, as well as ferromanganese, was used, and the sintering temperature was increased, ductile dimpling and failure through bainite colonies were observed. Increasing the sintering temperature above the melting point of the added ferromanganese $\left(1227^{\circ} \mathrm{C}\right)$ caused the transient liquid phase to aid sintering and strengthen the necks, and thus transfer the area of fracture to the weaker, transparticle regions. With the combination of additives and activators/energizers, as well as higher sintering temperature, an increase of transparticle fracture was also observed. The observations showed that failure mechanisms are strongly dependent on matrix microstructure and pore localization. Kabátová et al. [21, 22] and Dudrová et al. [23] reported that e.g. for PM Fe-1.5Cr-0.2Mo-0.7C and PM Fe-Ni-Cu-Mo steels, microcrack nucleation, growth and propagation dictate tensile strength and that prior particle boundaries are preferential paths for microcracking in static loading.

All the samples sintered at the lower temperature exhibited a substantial amount of brittle failure. It should be noted that only in the steel sintered at $1250^{\circ} \mathrm{C}$ are there extensive regions of dimple rupture, shown in Figs. 9 and 10. Figures 9 and 10 compare dimple distribution in specimens $\mathrm{E}$ and I. Noted in specimens $\mathrm{E}$ and I were predominantly dimple rupture and transgranular fracture surfaces, which indicates that the grain/interparticle boundaries were more fail-

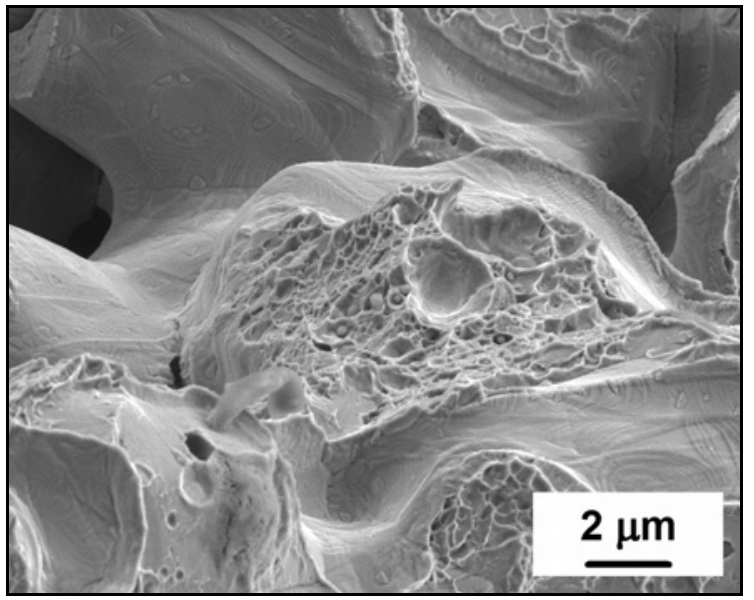

Fig. 9. Fractograph of specimen E after sintering at $1250^{\circ} \mathrm{C}$ for $60 \mathrm{~min}$.

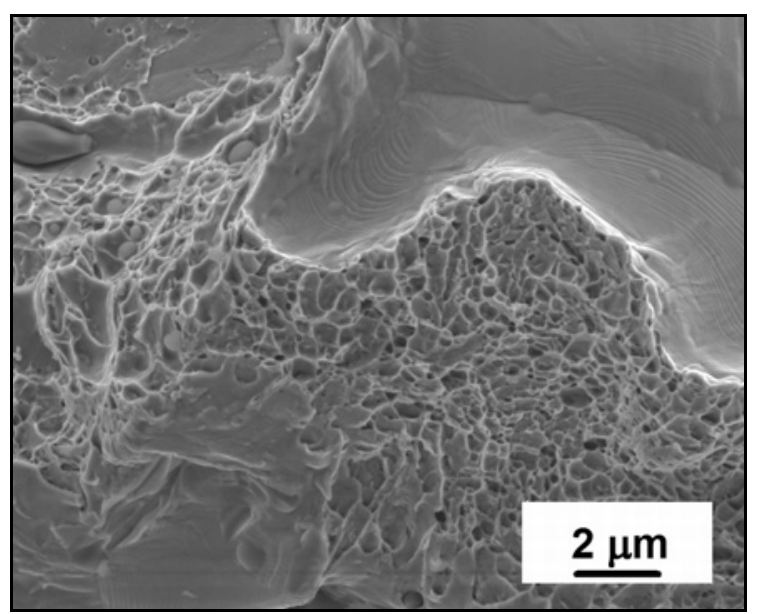

Fig. 10. Fractograph of specimen I after sintering at $1250^{\circ} \mathrm{C}$ for $60 \mathrm{~min}$.

ure resistant. The fracture surfaces of the specimens sintered at $1120^{\circ} \mathrm{C}$ with the large inclusions densities, comprised equiaxed dimples, with diameters comparable to the inclusion spacing, whereas, for the specimens sintered at $1250{ }^{\circ} \mathrm{C}$, a wide range of dimple sizes was found, of average diameters much smaller than the inclusion spacings. It should be added that sinter neck areas in specimens sintered at $1250^{\circ} \mathrm{C}$ also appear larger. Due to better homogenization, local Mn content was reduced, and ductile rather than brittle fracture on this micro scale was favoured. For a detailed discussion of intergranular failure, the reader is referred to E. Hryha et al. [20].

\section{Discussion}

Table 2 lists the high mechanical properties of 
FL-4605 steel, currently used for PM structural parts (MPIF Standard 35), and those of a recently researched steel produced from a lean pre-alloyed Cr-containing Astaloy CrA powder with $1.8 \% \mathrm{Cr}[25$, 26]. Astaloy $\mathrm{CrA}$ needs an addition of $1.0 \% \mathrm{Cu}$ or $2.0 \% \mathrm{Ni}$ to affect hardening under typical sinterhardening conditions [27]. Sinter-hardened Fe-2Ni$-1.8 \mathrm{Cr}-0.55 \mathrm{C}$ steel, produced from Astaloy CrA powder (sintering temperature $1120^{\circ} \mathrm{C}$, time $30 \mathrm{~min}$, atmosphere $90 \% \mathrm{~N}_{2} / 10 \% \mathrm{H}_{2}$, cooling rate $\sim 94 \mathrm{~K} \mathrm{~min}^{-1}$, sintered density $7.04 \mathrm{~g} \mathrm{~cm}^{-3}$ ), has properties listed in the last row of Table $2[25,26]$. It is seen that $0.4 \mathrm{C}$ $-1.4 \mathrm{Cr}-1.3 \mathrm{Ni}-0.7 \mathrm{Mn}-0.2 \mathrm{Mo}-0.2 \mathrm{Si}$ (lower $\mathrm{Ni}$ content) steel sintered at $1250^{\circ} \mathrm{C}$ can attain similar property values, taking into account a lower sintered density. The materials C, D, E, G, and I exhibited a good combination of tensile strength and tensile ductility. Although sinter hardened specimens may appear to have similar transverse rupture strength, it is important to remember that the cross-section of these test bars $(6 \mathrm{~mm} \times 6 \mathrm{~mm})$ may not be representative of many PM parts. Parts with larger cross-sections may not have the bainitic/martensitic microstructure of the ISO 2740 specimens - they may contain higher amounts of pearlite. Preliminary results detect marked differences between various heat treatments, but the indications are that, for the now investigated steel, sinter-austempering $1120^{\circ} \mathrm{C} / 500^{\circ} \mathrm{C}$ is the optimum (so far explored) processing procedure.

The best combination of properties, sintering at $1250{ }^{\circ} \mathrm{C}$ (involving a liquid phase) including strain-tofailure of nearly $5 \%$, was for variant $\mathrm{E}$ : $\mathrm{N}_{2}$ furnace atmosphere, naphthalene, $\mathrm{Na}_{2} \mathrm{CO}_{3}$. These data are slightly better than when ferromanganese, $\mathrm{Al}, \mathrm{NH}_{4} \mathrm{I}$ and $\mathrm{NaCl}$ activators were present, variant I. A synergistic effect of combining nascent carbon and manganese vapour (variants D and F) was thus then not observed at $1250^{\circ} \mathrm{C}$.

For sintering at $1120^{\circ} \mathrm{C}$, it was variant $\mathrm{G}, \mathrm{N}_{2}$ furnace atmosphere, ferromanganese powder, $\mathrm{Al}, \mathrm{NH}_{4} \mathrm{I}$, $\mathrm{NaCl}$, sinter-austempered at $500^{\circ} \mathrm{C}$, that came out best. It outperformed $\mathrm{B}$ and $\mathrm{F}$ and $\mathrm{H}$ sintered at 1120 and $1250^{\circ} \mathrm{C}$, as well as D sintered at $1120^{\circ} \mathrm{C}$, and the properties were significantly better than obtained with $1250^{\circ} \mathrm{C}$ conventional sintering (A).

Since the introduction of naphthalene into a semiclosed container is a recent innovation $[15,18]$, it is interesting to consider the pyrolysis of naphthalene in detail. At $1000^{\circ} \mathrm{C}$, partial graphitization starts. When this compound is pyrolyzed in the gas-phase, the pyrolysis can yield nanocarbon black or soot aerosol $[28,29]$. Transition metals and their oxides are efficient catalysts for pyrolysis reactions. Manganese oxide materials have been used for a wide range of catalytic pyrolysis reactions. The catalytic decomposition of hydrocarbons on manganese (II) oxide was extensively investigated [30, 31]. Manganese oxides are highly active catalysts for $\mathrm{CO}$ oxidation. The catalytic activity of manganese ferro-spinels in pyrolysis of naphthalene has been successfully developed to synthesize carbon nanoparticles (CNPs). This helps to explain the synergetic action of naphthalene and manganese for the $1120^{\circ} \mathrm{C}$ solid state sintering.

The introduction of ferromanganese powder together with $\mathrm{Al}$ and $\mathrm{NH}_{4} \mathrm{I}, \mathrm{NaCl}$ activators/energizers into a semi-closed container was the second innovation. When specimens $\mathrm{G}$ and I were sintered, the steel was aluminized in a semi-closed container containing pure aluminium (thermodynamic activity $=1$ ) and $\mathrm{NaCl}$, as the activator. The following equilibria pertain [32]:

$$
\mathrm{Al}_{(\mathrm{l})}+\mathrm{NaCl}_{(\mathrm{l})} \leftrightarrow \mathrm{AlCl}_{(\mathrm{v})}+\mathrm{Na}_{(\mathrm{v})}
$$

$\mathrm{AlCl}_{2(\mathrm{v})}$ and $\mathrm{AlCl}_{3(\mathrm{v})}$ are also formed in the container. The most important reaction occurring on the substrate surface is the dissociation of the metal halide vapours $\mathrm{AlCl}$ or $\mathrm{AlCl}_{2}$, e.g.

$$
2 \mathrm{AlCl}_{(\mathrm{v})} \leftrightarrow \mathrm{AlCl}_{2}+\mathrm{Al}
$$

Direct transfer of aluminium by forming $\mathrm{Al}_{(\mathrm{v})}$ occurs only to a very small extent, because of the very low $\mathrm{Al}$ vapour partial pressure. It is proposed that the reaction with $\mathrm{Al}$ is responsible for the reduction of $\mathrm{Cr}, \mathrm{Mn}$, and $\mathrm{Si}$ oxides. These chemical reactions in the container are only a part of a series of steps in processing the alloy. In addition to understanding the thermodynamics, it is also necessary to analyze the kinetics to gain a full appreciation of the process.

It is obvious that sintering of PM steels in flowing atmospheres, in which the partial pressure of oxygen or oxidizing gases $\left(\mathrm{H}_{2} \mathrm{O}, \mathrm{CO}_{2}\right)$ exceeds, even only slightly, the dissociation pressure of oxides of the elements of the alloy being sintered, leads to oxidation of the sintered parts $[33,34]$. Most chemical reactions are equilibrium systems; therefore, it is an advantage of micro-atmosphere sintering that the reaction products of interest usually have a higher volatility and thus are removed from the semi-closed container into the furnace atmosphere, shifting the chemical reaction to completeness. Use of semi-closed containers with labyrinth or melted glass seals for sintering PM steels makes it possible to dispense with drying of special flowing atmospheres or sintering without a flowing gas environment. Semiclosed containers substantially lower the sintering atmosphere costs, which are much higher for furnaces with a controlled protective atmosphere than for furnaces with an uncontrolled atmosphere [35].

Vacuum sinter-austempering treatment of some Cr-Mo steels was investigated to obtain a fully lower bainitic microstructure [36]. Once the cooling strategy had been set up, austempering was combined to sin- 
tering in a single process. Mechanical properties are slightly lower than those attainable with hardening, but pieces do not require any tempering. A further improvement of the properties and lowering the cost of the sinter-hardening treatment may be expected with the use of semi-closed containers and a flowing furnace atmosphere. Although mechanical properties attained when the air was the furnace gas were slightly inferior to those for nitrogen, it should be pointed out that they were markedly superior to those for conventional sintering at both temperatures, in $\mathrm{N}_{2}-5 \% \mathrm{H}_{2}$. They still compare favourably with mechanical properties attained by conventional sintering of components of current structural steels. Increasing the processing temperature to $1250^{\circ} \mathrm{C}$ results in a significant improvement of the properties. This is due to a lower oxygen content and is easy to obtain, even with protective atmospheres of relatively poor quality. Should $1250^{\circ} \mathrm{C}$, or a higher temperature, be required for sintering components that match properties of wrought steels, use can be made of furnaces designed for sintering ceramics. The author suggests that this opens new possibilities for PM.

\section{Conclusions}

1. Semiclosed containers for sintering PM steels make possible generation within the container of any gaseous environment necessary for the removal of oxide films. The sintering process for metals having a high affinity for oxygen can be combined with a chemo-thermal (for instance carbothermal) treatment, using getters. Thus, a low partial pressure of $\mathrm{O}_{2}, \mathrm{H}_{2} \mathrm{O}$, and $\mathrm{CO}_{2}$ in a sealed volume of the container can be established.

2. Cr-Ni-Mn-Mo-Si steels can be successfully sintered in semi-closed containers with nitrogen or air as the furnace gas. Generally, mechanical properties are superior to those obtained by conventional sintering in a flowing $\mathrm{N}_{2}-95 \% \mathrm{H}_{2}$ atmosphere. They compare favourably with those of many currently used PM structural steels.

3. Mechanical properties of Fe-1.4Cr-1.3Ni-0.7Mn-0.2Mo-0.2Si-(0.5-0.6) C are enhanced when sintering takes place in a semi-closed container with ferromanganese and/or naphthalene additives, or with ferromanganese, $\mathrm{Al}, \mathrm{NH}_{4} \mathrm{I}, \mathrm{NaCl}$ additives. The optimum results included yield strength of $\sim 400 \mathrm{MPa}$, TS above $800 \mathrm{MPa}$ and up to $4.5 \%$ strain-to-failure.

4. Expectedly sintering at $1250^{\circ} \mathrm{C}$ outperforms that at $1120{ }^{\circ} \mathrm{C}$. It should prove possible to process at higher temperatures PM steels in conventional air furnaces - for sintering ceramics - in semi-closed containers containing an environmentally friendly source of nascent carbon. Sintering can then be to higher density with mechanical properties of the steels matching those of their wrought counterparts.

5. The key to making a tough Cr-Mn-Si PM steel is to determine the mechanism by which oxide films and inclusions can be removed from the alloy. Obviously, the mere absence of oxides is not a sufficient criterion for high toughness or ductility of a PM steel.

\section{Acknowledgements}

This work was sponsored by the Polish Ministry of Science and Higher Education under Contract no. 11.11.110.299. Appreciation is also expressed to Prof. A. S. Wronski for his advice and comments on the manuscript as well as support for editing.

\section{References}

[1] Sułowski, M., Ciaś, A., Stoytchev, M., Andreev, T.: Materials Science Forum, 534-536, 2007, p. 753. doi:10.4028/www.scientific.net/MSF.534-536.753

[2] Sułowski, M., Ciaś, A., Frydrych, H., Frydrych, J., Olszewska, I., Goleń, R., Sowa, M.: Materials Science Forum, $534-536$, p. 757 . doi:10.4028/www.scientific.net/MSF.534-536.757

[3] Hryha, E., Dudrova, E., Nyborg, L.: Metallurgical and Materials Transactions A, 41, 2010, p. 2880. doi:10.1007/s11661-010-0357-5

[4] Sigl, L. S., Delarbre, P.: Advances in Powder Metallurgy \& Particulate Materials. Part 7. Princeton, Metal Powder Industries Federation 2003.

[5] Arvidsson, J., Tryggmo, A.: In: Proceedings of 1998 PM World Congress. Part 2. Eds.: Arnhold, V., Romero, A. Shrewsbury, European Powder Metallurgy Association 1998, p. 253.

[6] Bergman, O., Lindqvist, B., Bengtsson, S.: Materials Science Forum, 534-536, 2007, p. 545. doi:10.4028/www.scientific.net/MSF.534-536.545

[7] Ortiz, P., Castro, F.: Powder Metallurgy, 47, 2004, p. 291. doi:10.1179/003258904225020747

[8] Danninger, H., Chen, Xu, Lindqvist, B.: Materials Science Forum, 534-536, 2007, p. 577. doi:10.4028/www.scientific.net/MSF.534-536.577

[9] Pieczonka, T., Sułowski, M., Ciaś, A.: Archives of Metallurgy and Materials, 57, 2012, p. 1001. doi:10.2478/v10172-012-0112-6

[10] Campos, M., Sicre-Artalejo, J., Munoz, J. J., Torralba, J. M.: Metallurgical and Materials Transactions A, 41, 2010, p. 1847. doi:10.1007/s11661-010-0212-8

[11] Cias, A.: Development and Properties of Fe-Mn-(Mo)-Cr-C Sintered Structural Steels. Krakow, AGH Uczelniane Wydawnictwa Naukowo-Dydaktyczne 2004.

[12] Sulowski, M., Cias, A.: In: Proceedings of PM 2010 World Congress. Shrewsbury, European Powder Metallurgy Association 2010, p. 103.

[13] Dudrova, E., Kabatova M., Bidulsky, R., Wronski, A. S: Powder Metallurgy, 47, 2004, p. 181. doi:10.1179/003258904225015518

[14] Mitchell, S. C., Cias, A.: Powder Metallurgy Progress, 4, 2004, p. 132.

[15] Cias, A.: Powder Metallurgy, 56, 2013, p. 231. $\underline{\text { doi: } 10.1179 / 1743290112 Y .0000000048}$ 
[16] Salak, A., Selecká, M.: Manganese in Powder Metallurgy Steels. Cambridge, Cambridge International Science Publishing Ltd. 2012. doi:10.1007/978-1-907343-75-9

[17] Fial, Ch., Dudrova, E., Kabatova, M., Kupkova, M., Selecka, M., Sulowski, M., Cias, A.: In: Proceedings of International Conference on Deformation and Fracture in PM Materials 2014. Eds.: Ballokova, B. et al. Košice, IMR SAS 2014, p. 20.

[18] Cias, A.: Science of Sintering, 45, 2013, p. 379. doi:10.2298/SOS1303379C

[19] Fedorchenko, I. M., Slys, I. G., Sosnowski, L. A.: Powder Metallurgy and Metal Ceramics, 16, 1972, p. 361. doi:10.1007/BF00797738

[20] Hryha, E., Nyborg, L., Dudrova, E., Bengtsson, S.: Powder Metallurgy Progress, 8, 2008, p. 109.

[21] Kabátová, M., Dudrová, E., Wronski, A. S.: Powder Metallurgy, 49, 2006, p. 363. doi:10.1179/174329006X128313

[22] Dudrová, E., Kabátová, M.: In: Proceedings of PM World Congress 2004. Volume 3. Eds.: Danninger, H. et al. Shrewsbury, European Powder Metallurgy Association 2004, p. 193.

[23] Dudrová, E., Kabátová, M., Kupková, M.: Kovove Mater., 40, 2002, p. 24.

[24] Cias, A., Mitchell, S. C., Watts, A., Wronski, A. S.: Powder Metallurgy, 42, 1999, p. 227. doi: $10.1179 / 003258999665567$

[25] Engström, U., Larsson, C., Szabo, Ch.: In: Proceedings of Euro PM20I3 Congress \& Exhibition. Volume 3. Shrewsbury, European Powder Metallurgy Association 2013, p. 301.
[26] Astaloy $^{\mathrm{TM}}$ CrA. www.hoganas.com/pmc.

[27] Khorsand, H., Ghaffari, M., Ganjeh, E.: Materials \& Design, 55, 2014, p. 979. doi:10.1016/i.matdes.2013.10.072

[28] Greinke, R. A., Lewis, I. C.: Carbon, 22, 1984, p. 305. doi:10.1016/0008-6223(84)90176-3

[29] Harris, P. J. F., Tsang, S. C.: Philosophical Magazine A, 76, 1997, p. 667. doi:10.1080/01418619708214028

[30] Charinpanitkul, T., Sano, N., Puengjinda, P., Klanwan, J., Akrapattangkul, N., Tanthapanichakoon, W.: Journal of Analytical and Applied Pyrolysis, 86, 2009, p. 386. doi:10.1016/j.jaap.2009.08.001

[31] Fitzer, E., Mueller, K., Schaefer, W.: Chemistry and Physics of Carbon, 7, 1971, p. 237.

[32] Pankratz, L. B., Stuve, J. M., Gokcen, N. A.: Thermodynamic Data for Mineral Technology. Bureau of Mines Bulletin 677. Washington, DC, U. S. Government Printing Office 1984.

[33] Hryha, E., Dudrova, E., Nyborg, L.: Journal of Materials Processing Technology, 212, 2012, p. 977. doi:10.1016/i.jmatprotec.2011.12.008

[34] Dudrová, E., Kabátová, M., Bureš, R., Bidulský, R., Wronski, A. S.: Kovove Mater., 43, 2005, p. 404.

[35] Hotchkiss, A. G., Webber, H. M.: Protective Atmospheres. New York, John Wiley \& Sons, Inc. 1953.

[36] Girardini, L., Molinari, A., Locatelli, G., Tonini, G.: La Metallurgia Italiana, 2, 2006, p. 23. 